\title{
A policy window and a network of global and local policy entrepreneurs: The introduction of opioid substitution therapy in Belarus
}

\begin{abstract}
Why does a regime that is predominantly characterised by conservative ideology introduce opioid substitution therapy (OST), a liberal policy? This article applies the Multiple Streams Framework (MSF) to examine the introduction of OST in Belarus. Methodologically, the research draws on qualitative content analysis of drug policy documents and reports as well as on interviews. Results show how an increased HIV prevalence among injecting drug users opened a policy window in the problem stream. The increase in HIV cases could be used by a network of global and local policy entrepreneurs to frame OST as a public health policy instead of a drug policy measure. Findings suggest that, in nondemocratic regimes, global policy entrepreneurs can play a dominant role in introducing new policy ideas. However, the sustainability of the policy change remains questionable when acquiescence by key policymakers is lacking.
\end{abstract}

KEYWORDS: Drug Policy, Opioid Substitution Therapy, Belarus, Multiple Streams Framework

RECEIVED 28 February 2020; ACCEPTED 23 January 2021.

\section{INTRODUCTION}

In 2007, Belarus introduced opioid substitution therapy (OST). OST aims to reduce some of the negative consequences of drug use by substituting intravenous drugs, such as heroin, with medically prescribed replacement drugs. OST is seen as an effective measure to reduce the risk of HIV transmission and to improve the lives of intravenous drug users. Several Western European states that follow a liberal drug policy have introduced OST since the 1990s. Drug policy in Belarus, however, focuses on repression and the criminalisation of drug users. This article aims to answer the question of why Belarusian policymakers have liberalised their repressive drug policy regime by introducing OST.

International governmental and non-governmental organisations such as the Global Fund to Fight AIDS, Tuberculosis and Malaria (the Global Fund), UNAIDS, UNDP and WHO promote the introduction of OST (Global Fund, 2016; WHO, UNODC and UNAIDS, 2004). The Global Fund also financed the first OST programme in Belarus and most OST-related services until 2014. Hence, it may be assumed that the Global Fund played an important role in the drug policy change in Belarus.

This article examines the interplay of different factors that led to the introduction of OST in Belarus. To do so, we draw on the Multiple Streams Framework (MSF) (Herweg, Zahariadis, \& Zohlnhöfer 2017; Kingdon, 2014). The MSF argues that issues are more likely to be put on the agenda of policymakers and lead to policy change when three independent streams - the problem, politics and policy streams - meet, a policy window opens and a policy entrepreneur promotes agenda change (Herweg et al. 2018; Kingdon 2014). The MSF originally focused on policymaking in democratic regimes and on the influence of domestic policymakers. The MSF is now increasingly being applied to non-democratic regimes (e.g., Bindman, Kulmala, \& Bogdanova, 2019; Huang, 2006; Knutsen, 2012; Mu, 2018; Peng, Skinner \& Sperling, 2018; Schlaufer, 2019a; van den Dool, 2020; Wan, Chen \& Sperling, 2018; Zhou and Feng 2014; Zheng, 2017), and recent studies have included the role of international actors (Bache, 2013; Bache \& Reardon, 2013; Cairney, 2009; Lovell, 2016; Shephard et al., 2020). We draw on this recent literature to argue that in nondemocratic regimes, global policy entrepreneurs may play a prominent role to introduce new policy ideas. To back this argument, we also draw on the literature on transnational advocacy networks (Keck \& Sikkink, 1998, 1999) that shows how, in illiberal contexts,

1 National Research University, Higher School of Economics, Moscow, Public Policy Department 
local policy actors are frequently supported by international partners to influence policy change.

Our findings show that the introduction of OST was made possible because an increased HIV prevalence among injecting drug users opened a policy window that was seized by a network of global and local policy actors. This increase in HIV infections put the problem of HIV/AIDS on the agenda and allowed policy entrepreneurs to frame OST as a public health policy and not as a drug policy. Local governmental actors from the medical community and non-governmental organisations (NGOs) had advocated for the introduction of OST, but only the financial support of the Global Fund made OST a reality. Methodologically, we back our arguments with data drawn from systematic document analysis and interviews with stakeholders of the Belarusian drug policy subsystem.

With this article we aim to contribute to the body of literature on the MSF and Belarusian drug policy. To date, there is hardly any academic literature on drug policy in Belarus; the available literature consists of reports by international organisations, NGOs and the Belarusian government. Among those, only a few studies focus on OST (e.g., Aizberg, 2008). No previous study has discussed how OST found its way into one of the most repressive drug policy subsystems in the region of Central and Eastern Europe. Moreover, the article contributes to the MSF by providing a rare application to a non-democratic context and by highlighting the predominant role of global policy entrepreneurs in promoting new policy ideas.

The article proceeds as follows: the next section describes the drug policy context in Belarus. Then, the theoretical framework is introduced and expectations for our case are developed. The methodological section describes the procedure of data collection and analysis. Subsequently, the findings on the introduction of OST are presented, and the implications for the sustainability of OST in Belarus are discussed.

\section{THE POLICY CONTEXT: DRUG POLICY IN BELARUS AND THE GLOBAL FUND}

When it gained independence in 1991, Belarus built its drug policy regime on the legislation inherited from the Soviet period. In the Soviet Union, drug policy focused on prohibition and criminalisation. Accordingly, Belarusian drug policy has a strong focus on criminalisation and the repression of drug users. For example, the legislation does not differentiate between penalties for possession of illegal substances by amount or type, so possession of small amounts of soft drugs can be punished with long prison terms. The focus on repression has remained, and new legal acts consolidate the repressive regime.

However, this repressive policy regime has not proven to be an effective means of eradicating drug use but rather forced drug users to hide and abstain from accessing medical services. Furthermore, the prevalence of HIV cases among injecting drug users is widespread and cannot be addressed through repressive policies (UNAIDS, 2017).

Despite this repressive drug policy regime, OST was introduced in Belarus in September 2007. First, an OST pilot project started in the Gomel regional narcological dispensary. This project was financed by the Global Fund and implemented by the local UNDP office (The Global Fund, 2004). The programme grew from one site in 2007 to 19 sites across the country in 2017 providing therapy to around 900 people (UNAIDS, 2017). Overall, the initiative covers less than 5\% of the injecting drug users residing in the country (UNAIDS, 2017). Until 2014, the Global Fund supported around $80 \%$ of the total cost of the OST treatment in Belarus. Since 2014, OST treatment costs are largely financed by the Belarusian government; the Global Fund continues financing the procurement of methadone, which is a minor part of the total costs. Since 2015, the Global Fund programmes are implemented by a state institution affiliated with the Belarusian Ministry of Health - the Republican Scientific and Practical Centre of Medical Technologies, Informatisation, Management and Economics of Public Health.

\section{THEORETICAL FRAMEWORK: THE MULTIPLE STREAMS FRAMEWORK}

The central aim of the MSF is to explain why certain ideas capture the attention of policymakers while others do not (Herweg et al., 2017; Kingdon, 2011). According to the MSF, problems (what is defined as a public problem?), policies (what viable policy solutions are available?) and politics (how receptive are policymakers to these policies?) are crucial for an idea to become part of the policy agenda (Cairney, 2011; Herweg et al., 2017). The MSF delineates three independent 'streams': the problem, politics and policy streams. The problem stream comprises all issues that potentially could be addressed by the government. In the policy stream, policy 
solutions are generated by a policy community. Certain members of the policy community usually act as policy entrepreneurs, that is, as advocates who invest their resources to push for their preferred policy solutions. The politics stream is composed of political events, such as changes in governments or the pressures applied by interest groups.

The central argument of the MSF is that agenda and policy change become possible when these three streams conjoin (Herweg et al., 2017; Kingdon, 2011). The three streams only meet at particular moments in time when a window of opportunity or policy window opens. A policy window may open when a change happens in the problem stream, that is, policymakers perceive a problem to become pronounced, for example, when indicators negatively change, due to feedback on an existing policy, or when a focusing event occurs. A policy window can also open in the political stream through changes in political events (for example, a new government comes to power, interest groups apply increasing pressure or the national mood changes). When a policy window opens, policy entrepreneurs can seize the opportunity to push their policy solutions. To do so, they attach their preferred policy solution to a problem and find politicians who are receptive to their ideas, thereby bringing the three streams together.

\section{The MSF in a Non-democratic Institutional Setting}

The MSF has developed detailed hypotheses about what makes agenda change more likely (Herweg et.al, 2017, p.30), but these hypotheses have been developed in a democratic institutional context. Belarus is characterised in all commonly used democracy indices and regime classifications as autocratic (Coppedge et al., 2011; Freedom House, 2019; The Economist Intelligence Unit, 2019). Extant applications of the MSF to non-democratic regimes (e.g., Bindman et al., 2019; Hammond 2013; Huang, 2006; Knutsen, 2012; Liu and Jayakar 2012; Mu, 2018; Peng et al., 2018; Schlaufer, 2019a; Taylor, 2014; van den Dool, 2020; Wan et al., 2018; Zhou and Feng 2014; Zhu 2008; Zheng, 2017) have shown that the central idea of the MSF - that policies need to be coupled to problems in a conducive political context - is well applicable to non-democratic settings. Nonetheless, the processes in the problem, politics and policy streams may differ in an authoritarian institutional context. Some MSF hypotheses can directly be applied to non-democratic settings, while others need to be adapted to the non-democratic context (Herweg et al., 2017; Schlaufer, 2019a; Shephard et al., 2020; van den Dool, 2020). ${ }^{2}$

Problem stream and policy window: The MSF proposes two similar hypotheses on how problems can capture the attention of policymakers. First, the MSF hypothesises that a policy window opens in the problem stream as a result of at least one of the following changes: change of indicators, focusing events, or feedback on policies. Related to this, a second hypothesis suggests that a condition can more successfully be framed as a problem the more an indicator changes to the negative, the more harmful a focusing event is, and the more definitely a government programme does not work as expected (Herweg et al., 2017, p.30).

In a non-democratic environment, policymakers may lack access to reliable indicators, and negative feedback on the policy may not be openly communicated (Huang, 2006; Wan et al., 2018). Autocratic regimes frequently restrict freedom of information. This restricted flow of information can lead to an information deficit of policymakers, as the media, non-governmental organisations and researchers can only restrictively investigate problems, and no institutionalised mechanisms exist to channel messages from nongovernmental actors to policymakers (Chan and Zhao 2016; Khmelnitskaya 2015; Liu and Jayakar 2012; Zhou and Feng 2014).

However, several studies show that, also in non-democratic regimes, a change of indicators to the negative and negative feedback on existing policy can shed light on problems and open a policy window in the problem stream (Huang, 2006; Liu, Yamaguchi, \& Yoshikawa, 2017; Mu, 2018; Peng et al., 2018; Zheng, 2017). As in democracies, focusing events may also shift attention to a problem in non-democratic regimes (Bindman et al., 2019; Knutsen, 2012; Liu et al., 2017). ${ }^{3}$

For the introduction of OST in Belarus, we, therefore, formulate the following expectation:

2 The objective of this research is not to develop general hypotheses for the MSF in non-democratic institutional settings. Rather, we aim to select some of the MSF hypotheses that may explain the introduction of OST and test them in the non-democratic context of Belarus.

3 The MSF defines an additional hypothesis about policy windows in the problem stream. The MSF hypothesises that the more a condition puts a policymaker's re-election at risk, the more likely it is to open a policy window in the problem stream (Herweg et al. 2017, p.30). As this hypothesis is not relevant in a context without free and fair elections, this research does not include it. 
Expectation 1: The policy window for the introduction of OST in Belarus opened in the problem stream as a result of at last one of the following changes: change of indicators, focusing events or feedback.

Policy stream and policy entrepreneurs: In the policy stream, policy proposals are developed in policy communities. In non-democratic regimes, policymaking is centralised, and access to policymaking is restricted to a small elite, usually confined to the executive. Such a setting provides fewer opportunities for non-governmental actors to act as a member of policy communities or as policy entrepreneurs (Hammond 2013; Mu, 2018; Shephard et al., 2020; Taylor 2014; Zhou and Feng 2014). Nonetheless, also in non-democratic settings, actors from outside of the executive can develop policy ideas, be part of a policy community and act as policy entrepreneur but arguably to a lesser extent than in open democracies (Bindman et al., 2019; Duckett and Wang 2017; Zhu, 2008).

While the MSF has traditionally focused on domestic policymaking, more recent developments have shown how policy solutions are often developed internationally by experts working at international organisations, think tanks, NGOs or donor organisations (Bache, 2013; Bache \& Reardon, 2013; Cairney, 2009; Lovell, 2016; Meijerink \& Huitema 2010; Schlaufer, 2019b; Shephard et al., 2020). Policy communities are internationally connected, and local policy entrepreneurs frequently collaborate with global policy entrepreneurs (Shephard et al., 2020). This is particularly relevant for our case, as OST in Belarus was first financed through a grant by the Global Fund. Moreover, Shephard et al. (2020) suggest that in non-democratic contexts with restricted space for civil society, local policy entrepreneurs have fewer possibilities to influence policy, while global policy entrepreneurship can play a more prominent role.

It may be suggested that policy entrepreneurs frequently act in transnational advocacy networks (Keck \& Sikkink, 1998, 1999). Transnational advocacy networks involve actors who collaborate internationally on an issue and are "bound together by shared values, a common discourse, and dense exchanges of information and services' (Keck \& Sikkink, 1999, p.89). Transnational advocacy networks appear especially in contexts where local actors have fewer channels to influence their governments (Keck \& Sikkink, 1999, p.93). In such contexts, local civil society actors tend to seek support from international partners. While local actors may raise the salience of issues, advocate new ideas and lobby for policy change, international members of a network can provide important resources such as finance, capacity building or access to policymakers (Keck \& Sikkink, 1998; Shephard et al., 2020).

OST was an entirely new idea that became a policy alternative in Belarus despite the restrictive drug policy regime. The MSF hypothesises that new ideas are more likely to become viable policy alternatives, the more the integration of policy communities decreases (Herweg et al., 2017, p.30). The involvement of global actors in a policy community makes a policy community less integrated and may contribute to the emergence of new ideas. We argue that in non-democratic contexts the involvement of global actors in a policy community favours the introduction of new policy alternatives. We therefore formulate the following expectation for the case of the introduction of OST in Belarus: ${ }^{4}$

\section{Expectation 2: Collaboration between global and local policy entrepreneurs made the introduction of OST in Belarus more likely.}

The MSF also hypothesises that policy proposals are more likely to gain agenda status if they fulfil certain criteria, namely, technical feasibility, value acceptability, public acquiescence and financial viability (Herweg et al., 2017, p.30). MSF applications to nondemocratic regimes are inconclusive about the role of these criteria in non-democratic settings. While some studies argue that these criteria are also important, others demonstrate that policy proposals can reach agenda status even if they do not fulfil these criteria (Liu et al., 2017; Zhou and Feng, 2014; Zhu, 2008). However, most studies suggest that the most important criteria are the acquiescence of key decision-makers, be it a relevant minister, the president, or, an important actor of the ruling party (Gel'man and Starodubtsev, 2016; Li and Lu, 2018; Liu and Jayakar, 2012; Taylor, 2014). This suggests that policy proposals are most likely to survive in the policy stream if they are expected to be supported in the political stream.

Political stream: The MSF proposes the hypothesis that policy proposals that fit the general ideology of a government or the majority in a legislature have a better chance of gaining agenda status (Herweg et al., 2017, p.30). MSF applications to autocratic regimes show that this hypothesis may also be relevant in non-democratic regimes (Van den Dool, 2020; Zheng, 2017; Zhu, 2008).

4 The MSF also proposes the following policy entrepreneur hypothesis: 'Policy entrepreneurs are more likely to couple the streams successfully during an open policy window if (a) they have more access to core policymakers and (b) they are more persistent.' This research will not test this hypothesis but rather focus on how the collaboration of local actors with a global policy entrepreneur increased access to policymakers. 
However, this article aims to explain why a liberal drug policy measure could be introduced in Belarus, even though it assumably contradicts the general ideology of key governmental actors.

The introduction of the OST programme in Belarus may be considered a rather small policy change. It may be suggested that important policy decisions need to conform to the ideology of the government and need the acquiescence of the head of state. However, smaller policy changes can become possible, even if they contradict general ideology. Here, we expect that policy proposals that do not meet open opposition by key policymakers are more likely to gain agenda status. Therefore, we propose the following expectation to explain the introduction of OST in Belarus: ${ }^{5}$

Expectation 3: OST was not met with open resistance from key Belarussian policymakers.

\section{METHODOLOGICAL APPROACH}

To answer our research question of why OST was introduced in Belarus, we drew on secondary literature, qualitative content analysis of policy documents and reports, and semi-structured interviews. To select the documents for the analysis, we conducted a systematic search on the internet and asked interview partners for relevant sources. The examined documents included the Belarusian legal framework on drug policy and reports on HIV/AIDS by the Belarusian government, by international organisations, NGOs, and experts. Furthermore, we also included Belarusian websites on the topic (see Appendix 1 for a list of documents included in the document analysis).

In addition, four in-depth interviews were conducted. The selected interview partners were, first, a former Belarusian governmental official who had been responsible in the Ministry of Health for drug and alcohol addiction and for developing new approaches for treatment and prevention. The second interview was conducted with the deputy director of an NGO representing the interests of OST beneficiaries and people affected by drug addiction. Then, we included interviews with representatives of UNAIDS and the Global Fund. The interview partners were selected based on their knowledge of the introduction of OST at the time when OST was introduced. The four interviewees represent the most important governmental, as well as local and global non-governmental actors involved in the introduction of OST. The interviews were conducted in Russian over Skype between May 2019 and February 2020 and lasted between half an hour and an hour. The questions for the interview can be found in Appendix 2. The interviews were transcribed for analysis.

The interview transcripts and documents were analysed using qualitative content analysis (Mayring, 2010). We systematised the analysis along the MSF elements used in the three expectations to be tested. For the problem stream (expectation 1), we searched for any changes in problems related to drug use or HIV/AIDS. We searched for references to indicators, focusing events, or feedback on existing policies in documents and included an interview question on the problem stream (interview question 4, Appendix 2). For the policy stream (expectation 2), we searched for all relevant actors involved in the drug policy community and examined their policy proposals, stance towards OST, and collaboration among actors. Interview questions 1 and 2 concern the policy stream. For the political stream (expectation 3), we searched for the receptiveness of policymakers to OST (interview question 3). The texts were analysed by all three researchers, and the interpretation of the results was developed in a common deliberative process.

\footnotetext{
5 The MSF also suggests a hypothesis for policy windows opening in the political stream: 'The policy window opens in the political stream as a result of at least one of the following changes: changes in legislature or in the government, interest group campaigns, or a change in the national mood' (Herweg et al., 2017, p.30). In Belarus, the government and legislature have not significantly changed in the analysed period. In non-democratic settings, the role of interest groups outside of the government is also limited (Liu and Jayakar, 2012; Ge, Shi \& Wang, 2020; Zu \& Sun, 2009). The national mood is also likely to play a less important role in nondemocratic regimes - unless the national mood turns so negative that it endangers the regime (Herweg et al., 2017, p.45; Schlaufer, 2019a). We, therefore, assume that in the case of the introduction of OST in Belarus the policy window did not open in the political stream but in the problem stream, as proposed in hypothesis 1.
} 


\section{RESULTS: THE INTRODUCTION OF OST IN BELARUS}

\section{The Problem Stream: The Increase in HIV Indicators as a Policy Window}

Since the 1980s, the use of opiate-based drugs had increased in the former Soviet Union. Opiates were mainly used in the form of homemade drugs from locally grown poppy (Poznyak et al., 2002). During the transition period in the 1990s, drug use significantly increased in Belarus, and homemade opiates were increasingly substituted by heroin (Aizberg, 2008; Lelevich \& Vinitskaya, 2008; Lelevich et al., 2009; Poznyak et al., 2002; WHO, 2004). At the end of 2007, the registered number of intravenous drug users in Belarus was 76,281 people, which represents $1.3 \%$ of the country's population between the ages of 15 and 54 (Lelevich \& Vinitskaya, 2008).

Despite this increase in the number of drug users, the policy to respond to drug use did not change. Belarusian drug policy continued to focus on prohibition and criminalisation, as well as the provision of abstinence-oriented detoxification treatment offered by the governmental narcological service (interview, NGO representative; WHO, 2004). Drug use was mainly viewed as a problem of criminality, and the conviction and detention of people for drug-related crimes heavily increased in the 1990s (interview, NGO representative; interview, UNAIDS; WHO, 2004). Only a small minority of drug users voluntarily followed detoxification treatment out of fear of criminalisation, and due to low availability and quality of the treatment (Poznyak et al., 2002; WHO, 2004). Drug prevention and harm reduction approaches did not exist before the turn of the millennium.

The emergence of HIV/AIDS created a new dimension of the drug problem. At the end of the 1990s, Belarus witnessed an alarming increase in the rate of HIV transmissions. While the HIV situation in Belarus had been relatively stable between 1987 and 1995, with only 113 cases registered in January 1996, the situation changed in 1997, when the number of registered HIV-positive people suddenly rose to 1,134 (UNAIDS, 2018). The dramatic increase in HIV cases since 1996 was due to HIV transmission among injecting drug users (Lelevich et al., 2009; Poznyak et al., 2002). In 2001, the Department for HIV/AIDS Prevention in Belarus officially cited illegal drug use as the major cause for such a rapid increase (Darashchonak, 2007). At the end of 2007, 8,737 cases of HIV infection were officially registered, and in $60 \%$ of these cases, drug use was identified as the means of HIV transmission (Lelevich et al., 2009; UNAIDS, 2018).

Through this increase in the number of HIV infected people, the problem of HIV started receiving more attention in Belarus (Aizberg, 2008; Latypov, Bidordinova \& Khachatrian, 2012; Poznyak et al., 2002). According to all our interviewees, this negative change in HIV prevalence was crucial for the introduction of OST. The interviewed USAID representative explained, 'It was through the increase of HIV infections that we managed to introduce OST (...) The main route of HIV transmission in our country at that time was injecting drug use. Initially, OST was intended exclusively for drug users living with HIV. There was no broad vision of using OST as a harm reduction tool for drug users. Only later on, the programme started to include drug users who are not affected by HIV.'

The increase in HIV cases among drug users not only did raise attention to the problem of HIV among drug users but also allowed actors to re-frame drug use as a problem related to public health rather than to criminality. 'To launch the program, we promoted the message that HIV prevalence among injecting drug users in Belarus was high, and OST was one of the effective measures to contain the spread of HIV infections in this group. (...) In fact, we have managed to introduce substitution therapy through HIV prevention' (interview, UNAIDS).

In summary, our data suggest that the increase of HIV indicators opened a window of opportunity in the problem stream to get the introduction of OST on the agenda of Belarusian policymakers. In addition, the increase in HIV cases allowed framing OST as a health issue rather than a drug issue.

\section{The Policy Stream: Local and Global Policy Entrepreneurs}

First attempts to introduce an OST programme in Belarus started in the year 2000 (Aizberg, 2008). The idea to introduce OST was put forward by a variety of actors. Most importantly, employees of governmental drug treatment institutions, members of the medical 
community and the Belarusian Psychiatric Association, ${ }^{6}$ and local NGOs promoted OST (Aizberg, 2008; interview, governmental official; interview, NGO representative). Another important actor was the local UNDP office that was very active in pushing for the introduction of OST (Aizberg, 2008; interview, Global Fund; interview, UNAIDS). Starting in 2002, a project proposal for an OST pilot programme was being prepared by the UNDP office in Belarus, in close collaboration with the Global Fund, with employees of the Ministry of Health, and a network of local NGOs (Government of the Republic of Belarus, 2003; interview, governmental official; interview, UNAIDS; Poznyak et al., 2002). Between 2004 and 2014, UNDP was responsible for the implementation of the OST programmes financed by the Global Fund.

According to all interviewees, the Global Fund was instrumental in pushing for the introduction of OST. The Global Fund was created in 2002 and has promoted and financed OST globally since its creation (The Global Fund, 2016). The OST programme in Belarus began functioning only through financial support from the Global Fund. In 2004, the Global Fund approved a first 6.8 million US Dollar two-year grant to Belarus for the HIV/AIDS response (Global Fund, 2004; Lelevich et al., 2009). This grant included the pilot introduction of OST in the Gomel region, which started operations in 2007. In 2006, Phase 2 of the programme was approved with funding of nearly 10 million US Dollar over three years. In 2009, the Global Fund approved a third phase (Global Fund, 2012; interview, Global Fund). The programme was implemented by UNDP in close collaboration with governmental actors and NGOs.

Moreover, the Global Fund made the introduction of OST a condition for the funding of other activities, including the funding for the fight against tuberculosis: 'The introduction of OST was a requirement of the Global Fund to continue its activities in Belarus', explained the NGO representative, who also noted that 'The OST programmes were to a large extent financed by the Global Fund until 2014. The Global Fund paid for the opening of new OST centres and the salary of doctors working there.'

The Global Fund not only was instrumental due to its financial support but also supported the collaboration among local and international actors. Countries receiving a grant from the Global Fund are required to create a national body to coordinate HIV policy (a so-called Country Coordinating Mechanism). This coordinating mechanism was created in Belarus in 2002, and it included governmental officials, representatives from UNAIDS, as well as representatives of NGOs and organisations of people living with HIV (Government of the Republic of Belarus, 2008). This network made it possible to foster exchange among local governmental and non-governmental actors and supported local NGOs to have access to policymakers (interview, Global Fund).

In summary, these data suggest that the introduction of OST was made possible through a collaboration of local policy entrepreneurs with the Global Fund. An interviewed governmental official speaks of 'a common effort on the part of national government officials and the Global Fund'. He also points to the importance of civil society actors, mainly potential OST beneficiaries and their families. Local policy entrepreneurs - above all lower government officials in the health sector and NGO representatives - did not have sufficient access to policymakers. The Global Fund, as a global policy entrepreneur, could create this access and had leverage through financial resources to push for the adoption of OST.

\section{The Politics Stream: How Receptive Were Key Policymakers to OST?}

The introduction of OST would not have been possible without the official approval of the Belarusian government. An interviewee from the Global Fund notes that 'The UNDP office implemented the actual work to introduce the treatment in close cooperation with the Ministry of Health, the Ministry of Internal Affairs and the Ministry of Justice'. The introduction of OST was legally made possible through two decrees of 2005 and 2007 by the Belarusian Ministry of Health.

However, the introduction of OST also encountered resistance from key policymakers. Most importantly, representatives from the Ministry of Internal Affairs - and in particular the Minister of Interior at the time - openly opposed the introduction of OST (interview, NGO representative; interview, UNAIDS). The interviewed NGO representative explained: 'We encountered very strong resistance from the Ministry of Internal Affairs, which was in the beginning categorically against such a treatment. (...) People from

6 The Belarusian Psychiatric Association (BPA) is an NGO consisting of psychiatrists, narcologists, psychotherapists and psychologists. The organisation's main goals are the protection of the rights of people suffering from mental disorders as well as improving the quality of medical care delivered to them. 
the Ministry of Internal Affairs see in drug users criminals and not patients.' This was confirmed during the interview with UNAIDS: 'In fact, the previous minister was against it, and he always stressed that this was his personal opinion. When the minister has such an opinion, the ministry itself does not particularly advertise its support.'

Despite this resistance, the introduction of the OST programme was officially approved. Three interviewees explained that the pressure from the Global Fund for OST and the support by other governmental actors were crucial. Because OST was introduced as a policy to address HIV, the Ministry of Health could take the lead, instead of the Ministry of Internal Affairs that is responsible for drug matters. The Ministry of Health has been much more favourable of the programme (interview, NGO representative; interview, UNAIDS).

In addition, the interviewed governmental official explained that the resistance of the Ministry of Interior could be overcome because OST remains a small programme, and it does not challenge the overall repressive drug policy: 'There is no need to liberalize. Our approach is balanced in terms of the availability of drug treatment to drug users and, at the same time, there is a severe but fair punishment for drug distribution' (interview, governmental official).

In summary, these data suggest that OST could be introduced despite the resistance from the powerful Ministry of Internal Affairs. Most importantly, through the re-framing of OST as a public health policy and not a drug policy, the Ministry of Health that was more supportive to OST could initiate the change. Second, OST has remained a small programme and has not involved a change of the general repressive drug policy approach.

\section{DISCUSSION: IS THE INTRODUCTION OF OST A SUSTAINABLE POLICY CHANGE?}

This article has asked the question of why Belarusian policymakers have liberalised a repressive drug policy regime by introducing OST. Drawing on the MSF, we have developed three expectations on what factors favoured the introduction of OST.

First, our data confirmed that a change of the indicator on HIV cases among drug users opened a policy window for the introduction of OST (Expectation 1). This change of indicators to the negative raised attention to the problem of HIV among injecting drug users and allowed to frame OST as a health policy measure. Other potential triggers to open a policy window, such as focusing events, were not found in the examined documents or mentioned in the interviews.

Second, the policy window was used by a network of actors to promote OST (Expectation 2). All interviewees and the examined reports point to the prominent role of a global policy entrepreneur - the Global Fund - in pushing for the introduction of OST. However, the Global Fund did not act alone but rather in a network of local and international actors who shared a common objective and exchanged knowledge and information. This network included Belarusian governmental actors, mainly from the health sector, as well as NGOs. The local actors were in contact with drug users and HIV patient and could raise attention to the problem and advocate OST locally. The global actors brought knowledge, finance and access to high-level policymakers.

However, not all governmental actors were receptive to the policy change, as shows the resistance towards OST in the Ministry of Internal Affairs. Our Expectation 3 - that OST was not met with open resistance from key Belarussian policymakers - could not be confirmed by our data. The leading role of the supportive Ministry of Health and the small size of the OST programme may explain this finding.

The important role of international donor organisations in introducing this new policy raises the questions of how sustainable OST in Belarus is and how it might be locally managed. Our document analysis and interviews point not only to challenges in achieving local ownership and sustainability but also to positive developments.

Firstly, the scope of the OST program in Belarus remains small. The treatment centres across the country reach less than $5 \%$ of injecting drug users (UNAIDS, 2017). In order to lower the number of new HIV cases, the WHO recommends increasing coverage to $40 \%$ of injecting drug users (WHO, 2014). 'The coverage is too low to reduce the HIV incidence' (interview, UNAIDS). OST in Belarus is, thus, hardly an effective intervention to reduce the spread of HIV. Secondly, OST is not implemented in a beneficiaryfriendly manner. This lack of access to user-friendly OST sites raises the questions of how the programme might be locally managed and developed. The interviewees from the Global Fund and UNAIDS explained that in order to increase access to OST, the Belarusian OST guidelines need to be revised: 'the revision has been going on for three years, and we are still waiting for the approval of the new document' (interview, Global Fund). The interviewed NGO representative asserts that the Ministry of Health would have the means to increase access but political will is lacking. He maintains that OST is not sufficiently supported by local governmental actors: 'I 
believe that if the Global Fund leaves, the OST centres will slowly disappear.' Statistical data tend to support his claim: According to UNAIDS, more than 1000 beneficiaries were enrolled on the OST programme in 2014 (UNAIDS, 2018). After the Global Fund seized to finance the opening of new OST centres in 2014, OST coverage was reduced to 900 patients in 2017 (UNAIDS, 2017). 'In 2019, there were only 650 OST beneficiaries. (...) What happens next when the Global Fund leaves the country is a very big question' (interview, NGO representative).

However, there are also developments that point to a change in the attitude of governmental actors. Two more OST cabinets are scheduled to open in Belarus in 2020 (interview, NGO representative; interview, Global Fund representative; interview, governmental official). The UNAIDS representative maintains that the OST programme is now largely financed by the Government. Therefore, she is convinced that the programme continues working even after the Global Fund stops funding activities in Belarus. The interviewed NGO and UNAIDS representatives also assert that even inside the Ministry of Internal Affairs, OST is now an accepted policy and that the Ministry of Health openly praises the positive results of OST. 'The Ministry of Internal Affairs and the Ministry of Health have come to the conclusion that OST is the only possible way to effectively deal with the problem of drug use and the spread of HIV infection' (interview, UNAIDS).

The interviewee at the Global Fund also agrees that decision-makers in the ministries have recognised the importance of OST: 'The government is changing its vision, it is open to changes. They will not happen within a day or two but at least the trend is positive.'

\section{CONCLUSIONS}

The purpose of this article was to explain why a liberal policy was introduced in an authoritarian setting. Drawing on the MSF, we argued that a global policy entrepreneur, in collaboration with a network of local governmental and non-governmental actors, utilised a policy window to influence the domestic policy agenda. Resistance by local key policymakers could be overcome through the re-framing of OST as a public health and not a drug policy issue. An important question that remains partly unanswered is how sustainable this policy change is. On the one hand, the experience of OST might have already positively influenced attitudes inside the government. On the other hand, the failure to increase coverage and to revise OST regulations points to the possibility that the programme might be dismantled in the future.

More generally, this research points to the possibility of introducing liberal policies in non-democratic regimes through the constant advocacy of a transnational network of policy entrepreneurs. Our findings contribute to MSF scholarship in two ways. First, this research discusses the peculiarities of applying the MSF in a nondemocratic context. Thereby, it contributes to the emerging literature on the MSF in nondemocratic regimes. Our findings confirmed that, overall, the MSF can be applied in non-democratic regimes. Nonetheless, we only applied a selection of MSF hypotheses and adapted them to better fit the non-democratic context. Further research is needed to refine and test other MSF hypotheses. Second, we argue that in an illiberal context the collaboration of local and global policy entrepreneurs is crucial. To back our argument, we built not only on recent MSF research that focuses on the collaboration of local and global policy entrepreneurs (Shephard et al., 2020) but also on the literature on transnational advocacy networks. Future applications of the MSF in non-democratic contexts or developing countries should further investigate the collaboration of policy entrepreneurs in networks.

Our findings must also be considered in light of several limitations. First, these results have been deduced from one single policy field in the specific context of Belarus. Second, the case study includes only a small number of interviews. Due to the long time that has passed since the introduction of OST and the non-responsiveness of governmental actors, it turned out to be difficult to find additional interview partners. Nonetheless, representatives of the most important actors responsible for the introduction of OST in Belarus were among our interview partners. To address this limitation, we also triangulated interviews with a systematic document analysis. Despite these limitations and the clear need for further research, we believe that this article contributes to our understanding of the political context of drug policy in Belarus and the application of MSF in non-democratic settings. 


\section{APPENDIX 1: LIST OF DOCUMENTS INCLUDED IN DOCUMENT ANALYSIS}

Eurasian Harm Reduction Network. (2008). Opioid Substitution Therapy in Selected Countries of Eastern Europe and Central Asia. https:/www.iasociety.org/web/webcontent/file/19jan-iasyalta-ost\%20overview_eng\%20final\%20version-doc.pdf

European Monitoring Center for Drugs and Drug Addiction. Belarus country overview

https://www.emcdda.europa.eu/publications/country-overviews/by_en

Global Fund. (2004). Grant Agreement with UNDP.

https://data.theglobalfund.org/investments/location/BLR\#grants

Global Fund. (2006). Grant Agreement with UNDP.

https://data.theglobalfund.org/investments/location/BLR\#grants

Global Fund. (2009). Grant Agreement with UNDP.

https://data.theglobalfund.org/investments/location/BLR\#grants

Global Fund. (2012). Grant Performance Report.

https://data.theglobalfund.org/investments/location/BLR\#grants

Global Fund (2020) Grant portfolio Belarus. https://data.theglobalfund.org/investments/location/BLR\#grants

Global Fund. (2020). Harm reduction for people who use drugs. https://www.theglobalfund.org/media/1279/core_harmreduction_ infonote_en.pdf

Government of the Republic of Belarus. (2003). Report on monitoring the follow-up of the Declaration of Commitment on HIV/ AIDS. Reporting Period 2002. https://data.unaids.org/topics/ungass2003/europe/belarus_ungassreport_2003_en.pdf

Government of the Republic of Belarus. (2004). Strategic action plan to fight HIV/AIDS epidemic in the Republic of Belarus for 2004-2008, Minsk 2004

https://extranet.who.int/nutrition/gina/sites/default/filesstore/BLR\%202004-2008\%20hiv_plan_belarus_0.pdf

Government of the Republic of Belarus. (2008). National Report on the Implementation of the Declaration of Commitment on HIV/AIDS. Reporting Period 2006-2007.

https://data.unaids.org/pub/report/2008/belarus_2008_country_progress_report_en.pdf

Law of the Republic of Belarus of 20 December 2007 \291-3 Regarding Amending Several Laws of the Republic of Belarus on the Matters of Illicit Trafficking of Narcotic Drugs, Psychotropic Substances and Their Precursors.

Positivnoe Dvizhenie. (n.d.) Snizhenie vreda prabotaet. http://pmplus.by/reduction-works/

Pravitelstvo Respubliki Belarus. (2015). Nationalnii ochet o dostignutom progresse v osushchestvenii globalnikh mer v otvet na SPID. Otchetnii period: 2013-2014 https://www.unaids.org/sites/default/files/country/documents/BLR_narrative_report_2015.pdf

Resolution of the Ministry of Health of the Republic of Belarus of 1 July 2002 \ 46 Regarding the Approval of Regulations on Anonymous Medical Assistance

Resolution of the Ministry of Internal Affairs and the Ministry of Health of the Republic of Belarus of 19 September $2005 \otimes$ 293/33 Regarding Making Additions and Alterations to the Instruction Regarding the Identification and Registration of Persons Practicing Non-therapeutic Use of Drugs or Other Substances Inducing Intoxification, Handling and Referring Drug Patients to Compulsory Isolation.

Resolution of the Ministry of Health of the Republic of Belarus of 31 October 2007 99 Regarding the Approval of the Instruction of Issuing Doctor's Prescriptions and Amending Resolution of the Ministry of Health of the Republic of Belarus of 27 December 2006 冈 120

Tvoi Shans. (n.d.) Zamestitelnaia poderzhivaiushchaia terapia. http://yourchance.by/zamestitelnaya-podderzhivayushhaya-terap/

UNAIDS. (2008). The first 10 years. https://data.unaids.org/pub/report/2008/jc1579_first_10_years_en.pdf

UNAIDS (2011). Methadone substitution therapy helps prevent new HIV infections in Belarus. https://www.unaids.org/en/ resources/presscentre/featurestories/2011/march/20110302methadonebelarus

UNAIDS. (2014). Opioid substitution therapy and HIV prevention in Belarus. https://www.unaids.org/en/resources/presscentre/ featurestories/2014/december/20141211_Belarus\#: : :text=Belarus\%20aims\%20to\%20sustain\%20and,is\%20available\%20 at $\% 2018 \% 20$ sites

UNAIDS. (2017). Belarus: Reducing harm, preventing new HIV infections. https:/www.unaids.org/en/resources/presscentre/ featurestories/2017/april/20170412_belarus 
UNDP (n.d.) Methadone substitute helps prevent HIV infection.

https://www.by.undp.org/content/belarus/ru/home/ourwork/hiv_aids/successstories/methadone-substitute-helps-prevent-hivinfection.html

WHO. (2004). The practices and context of pharmacotherapy of opioid dependence in Central and Eastern Europe http://old.ntakd.lt/files/informacine_medzega/PSO_LEIDINIAI/3-Practices_and_Context_of_Pharmacotherapy.pdf

WHO, UNODC and UNAIDS. (2004). Joint position paper on substitution maintenance therapy in the management of opioid dependence and HIV/AIDS prevention. Geneva: World Health Organization.

\section{APPENDIX 2: QUESTIONS FOR THE SEMI-STRUCTURED INTERVIEWS}

1. What actors were involved in the development of OST in Belarus? How did these actors advocate for the introduction of OST?

2. How do you assess the role of the Global Fund in the introduction of OST?

3. What was and is the stance of the government and different ministries towards OST?

4. How important was the HIV problem for the introduction of the program?

5. How is OST currently funded? What will happen if the Global Fund withdraws its contribution?

6. Civil society activists point to problems such as the necessity to visit OST centres every day for the dose, the remoteness of the centres and their absence in the areas severely affected by drug use. What is done by the government and other organisations to improve the situation?

7. How do you evaluate the effectiveness of the OST programme in Belarus?

8. How would you evaluate the contemporary national drug policy of Belarus?

\section{REFERENCES}

Aizberg, O. 2008. Opioid Substitution Therapy in Selected Countries of Eastern Europe and Central Asia. Minsk: International AIDS Society and Eurasian Harm Reduction Network.

Bache, I. (2013). Measuring quality of life for public policy: an idea whose time has come? Agenda-setting dynamics in the European Union. Journal of European Public Policy, 20(1), 21-38.

Bache, I., Reardon, L. (2013). An Idea Whose Time has Come? Explaining the Rise ofWell-Being in British Politics. Political Studies, 61(4), 898-914.

Bindman, E., Kulmala, M., \& Bogdanova, E. 2019. NGOs and the Policy-making Process in Russia: The Case of Child Welfare Reform. Governance, 32(2), 207-22.

Cairney, P. (2009). The role of ideas in policy transfer: The case of UK smoking bans since devolution. Journal of European Public Policy, 16(3), 471-488.

Cairney, P. (2011). Understanding public policy: Theories and issues. Basingstoke: MacMillan.

Cairney P., Jones M.D., 2016. Kingdon's Multiple Streams Approach: What Is the Empirical Impact of this Universal Theory? Policy Studies Journal, 44(1), 37-58.
Chan, K., \& Zhao, S. (2016). Punctuated Equilibrium and the Information Disadvantage of Authoritarianism: Evidence from the People's Republic of China. Policy Studies Journal, 44(2), 134-155.

Coppedge, M., Gerring, J., Altman, D., Bernhard, M., Fish, S., Hicken, A., Kroenig, M., Lindberg, S. I., McMann, K., Paxton, P., Semetko, H. A., Skaaning, S., Staton, J., Teorell, J., \& A. Semetko, Svend-Erik Skaaning, J. S. and J. T. (2011). Conceptualizing and measuring democracy: A new approach. Perspectives on Politics, 9(2), 247-267.

Darashchonak, T. (9 July 2007). As many as 8,291 HIV infection cases reported in Belarus as of July 1. Belorusskie Novosty. http://new.naviny. by/en/rubrics/english/2007/07/og/ic_articles_259_151811

Duckett, J., Wang, G. (2017). Why do Authoritarian Regimes Provide Public Goods? Policy Communities, External Shocks and Ideas in China's Rural Social Policy Making. Europe-Asia Studies 69 (1): 92-109. doi:10.1 080/09668136.2016.1274379

Freedom House. (2019). Country Report Belarus. https://freedomhouse. org/country/belarus/freedom-world/2019

Global Fund. (2004). Program Grant Agreement with UNDP. Retrieved from: https://www.theglobalfund.org/en/portfolio/country/ list/?loc=BLR\&k=8f 5 db665-828c-456o-b959-155doe156azo 
Global Fund. (2012). Grant Performance Report. Retrieved from: https:// data.theglobalfund.org/investments/location/BLR\#grants

Global Fund. (2016). The Global Fund Strategy 2017-2022. Investing to End Epidemics. Geneva: The Global Fund. Retrieved from: https://www. theglobalfund.org/media/2531/core_globalfundstrategy2017-2022_ strategy_en.pdf

Hammond, D. R. (2013). Policy Entrepreneurship in China's Response to Urban Poverty. Policy Studies Journal, 41(1), 119-146.

Herweg, N., Zahariadis, N., \& Zohlnhöfer, R. (2017). The multiple streams framework: Foundations, refinements, and empirical applications. In C. M. Weible \& P. A. Sabatier (Eds.), Theories of the Policy Process (pp. 17-53).

Huang, Y. (2006). The politics of HIV/AIDS in China. Asian Perspective, 30(1), 95-125.

Keck, M.E. \& Sikkink, K. (1998). Activists beyond Borders: Advocacy Networks in International Politics. Ithaca: Cornell University Press

Keck, M. E., \& Sikkink, K. (1999). Transnational advocacy networks in international and regional politics. International Social Science Journal, 51(159), 89-101.

Khmelnitskaya, M. (2015). The policy-making process and social learning in Russia: The case of housing policy. Palgrave Macmillan.

Kingdon, J. (2011). Agendas, alternatives, and public policies. Essex: Pearson.

Knutsen, W. L. (2012). An Institutional Account of China's HIV/AIDS Policy Process from 1985 to 2010. Politics \& Policy, 4O(1), 161-192.

Latypov, A., Bidordinova, A. \& Khachatrian, A. 2012. Opioid Substitution Therapy in Eurasia: How to increase the access and improve the quality. London: IDPC Briefing Paper

Lelevich V., Vinitskaya H., 2008. Viral hepatitis prevalence among drug users in the Republic of Belarus. Actual Problems of Hepatology: 7 th International Symposium of Hepatologists of Belarus, Vitebsk

Lelevich, V., Vinitskaya, H., Lelevich S., Razvodovsky, Y., Maksimchuk, V., Medvedev, D. (2009). Drug abuse and illicit drug trafficking in the republic of Belarus in 2007. Minsk: Monitoring Centre for Drugs and Drug Addiction Grodno State Medical University.

Liu, C., \& Jayakar, K. (2012). The evolution of telecommunications policymaking: Comparative analysis of China and India. Telecommunication Policy, 36(1), 13-28.

Liu, D., Yamaguchi, K., \& Yoshikawa, H. (2017). Understanding the motivations behind the Myanmar-China energy pipeline: Multiple streams and energy politics in China. Energy Policy, 107, 403-412
Lovell, H. (2016). The role of international policy transfer within the multiple streams approach: the case of smart electricity metering in Australia. Public Administration, 94(3), 754-768.

Martinovich, N. (2012) Political system of Belarusian society: sociological analysis. Belorussian Sociological Almanac 3(1), 142-153

Mayring, P. (2010). Qualitative Inhaltsanalyse. In Handbuch Qualitative Forschung in der Psychologie (pp. 601-613). Wiesbaden: VS Verlag für Sozialwissenschaften.

Meijerink, S., Huitema, D. (2010). Policy Entrepreneurs and Change Strategies: Lessons from Sixteen Case Studies of Water Transitions around the Globe. Ecology and Society, 15(2), 17.

Mu, R. (2018). Coupling of Problems, Political Attention, Policies and Institutional Conditions: Explaining the Performance of Environmental Targets in the National Five-Year Plans in China. Sustainability, 10(5), 1477.

Peng, Q., Skinner, J., \& Houlihan, B. (2019). An analysis of the Chinese Football Reform of 2015: why then and not earlier?. International journal of sport policy and politics, 11(1), 1-18.

Poznyak,V.B., Pelipas, V.E., Vievski, A.N., and L. Miroshnichenko. (2002). Illicit Drug Use and Its Health Consequences in Belarus, Russian Federation and Ukraine. European Addiction Research. 8 (4), 184-189

Schlaufer, C. (2019a). Why Do Non-Democratic Regimes Introduce Online Citizen Participation? A Multiple Streams Perspective on Moscow's Active Citizen E-Voting Platform. Paper presented at the ECPR General Conference 2019 in Wroclaw.

Schlaufer, C. (2019b). How does policy advice of the international monetary fund differ along the income of advised countries?. Policy Studies, 40(3-4), 287-302.

Shelest O., Egorov A., \& Smolyanko O. (2018) Grazhdanskoe obschestvo Belarusi: actualnoe sostoyanie i usloviya razvitiya (available on Russian), Retrieved from http://belaruspolicy.com/sites/default/files/ articles/06.11.2018/2018_civil-society-belarus_ru.pdf

Shephard, D. D., Ellersiek, A., Meuer, J., Rupietta, C., Mayne, R., \& Cairney, P. (2020). Kingdon's multiple streams approach in new political contexts: Consolidation, configuration, and new findings. Governance.

Taylor, B. D. (2014). Police reform in Russia: the policy process in a hybrid regime. Post-Soviet Affairs, 30(2-3), 226-255.

The Economist Intelligence Unit. (2019). World Democracy Report.

UNAIDS. (2017). Country Report Belarus. Minsk: UNAIDS.

UNAIDS. (2018). Fact Sheet Belarus. https://www.unaids.org/ru/ regionscountries/countries/belarus 
Wan, Z., Chen, J., \& Sperling, D. (2018). Institutional barriers to the development of a comprehensive ballast-water management scheme in China: Perspective from a multi-stream policy model. Marine Policy, 91, 142-149.

WHO, UNODC and UNAIDS. (2004). Joint position paper on substitution maintenance therapy in the management of opioid dependence and HIV/AIDS prevention. Geneva: World Health Organization.

World Health Organization. (2014). How to improve Opioid Substitution Therapy implementation. http://www.euro.who.int/_data/assets/ pdf_file/0015/241341/How-to-improve-Opioid-Substitution-Therapyimplementation.pdf?ua=1:

World Health Organization. (2004).The practices and context of pharmacotherapy of opioid dependence in Central and Eastern Europe http://old.ntakd.It/files/informacine_medzega/PSO_LEIDINIAI/3Practices_and_Context_of_Pharmacotherapy.pdf

Yanushewskaya, A. (21 July 2008). Belarus applies to UN Global Fund for 25 million. Belorusskie Novosty. Retrieved from: http://new.naviny.by/ en/rubrics/english/2008/07/21/ic_articles_259_158108

Zheng, J. (2017). A Policy Analysis of the Development of Elite Swimming in China Between 2000 and 2012: A National Team Perspective. The International Journal of the History of Sport, 34(12), 1247-1274.

Zhou, N., \& Feng, F. (2014). Applying Multiple Streams Theoretical Framework to college matriculation policy reform for children of migrant workers in China. Public Policy and Administration, 4(10), 1-11.

Zhu, X. (2008). Strategy of Chinese policy entrepreneurs in the third sector: challenges of 'technical infeasibility'. Policy Sciences, 41, 315334 .

Van den Dool, A. (2020). The multiple streams approach in a nondemocracy: The issue of live poultry sales in China. Paper presented at the ECPR conference 2020, online. 